\title{
Early Detection of Ototoxicity by High-Frequency Audiometry - A Case Study
}

\author{
Gustav R. Voogt, BA(Log) (Pretoria) \\ Department of Otorhinolaryngology, \\ Medical University of Southern Africa.
}

\begin{abstract}
The effect of an ototoxic aminoglycoside antibiotic (tobramycin) on the hearing acuity of an adult Black female cardiac patient was evaluated with a new type of high-frequency audiometer. Results indicated the effectivity of this audiometer for the early detection of ototoxicity. The possibility of higher susceptibility to ototoxic damage in Blacks due to a higher concentration of melanin in the inner ear is discussed.
\end{abstract}

\section{OPSOMMING}

Die effek van 'n ototoksiese aminoglikosied antibiotikum (tobramycin/ op die gehoorsensiwiteit van 'n volwasse Swart vroulike hartpasiënt is geëvalueer met behulp van'n nuwe tipe hoëfrekwensieoudiometer. Resultate dui op die effektiwiteit van hierdie oudiometer vir die vroeë opsporing van ototoksisiteit. Die moontlikheid van 'n hoër vatbaarheid vir otoksiese skade by Swartes as gevolg van 'n hoër konsentrasie van melamien in die binneoor word bespreek.

Conventional diagnostic audiometry generally deals with assessment of auditory sensitivity for frequencies of $8 \mathrm{kHz}$ and below, even though humans can hear tones as high as 16 to $20 \mathrm{kHz}$. It has also been proven that ototoxic substances first cause a decline in the high-frequency hearing, i.e., above 10 $\mathrm{kHz}$ (Schuknecht, 1974).

Various drugs are known to be ototoxic. Of these, tobramycin is rated as highly ototoxic (Lane and Routledge, 1983). In these reports the ototoxic effects were determined by histologic examinations of the hair cell damage occurring in the cochlea and by measuring the resultant decline in hearing senśitivity as measured by conventional pure tone audiometry (Fee, 1980; Smith, Lipsky, Laskin, Hellmann, Mellits, Longstreth and Lietman, 1980; Matz, 1986). Ototoxic agents cause hair cells to begin to degenerate first at the very basal end of the organ of Corti, that part of the cochlea which is used to detect the highest frequencies the living animal can hear. This is a process that gradually and systematically progresses farther into the cochlea (Schuknecht, 1974). By the time this damaging effect becomes visible on a conventional pure tone audiogram valuable time for prevention has passed and permanent damage has been done to the high frequency region in the cochlea. Thus, by measuring high-frequency hearing, drug-induced ototoxic damage can be detected at a much earlier stage [Tonndorf and Kurman, 1984).

This preoccupation with testing may be explained by various mechanoacoustic problems encountered when trying to test for the higher frequency auditory thresholds. The biggest problem appears to be in calibration as the quarter and half wavelengths of the higher frequency sound approach ear canal width and length, causing transversal resonances and standing waves to occur. This means that the sound front impinging on the tympanic membrane no longer resembles the sound being fed into the external ear canal (Stinson, 1984; Tonndorf and Kurman, 1984). Logical- ly this also leads to immense problems when trying to mask the contralateral ear. A further problem seems to be to find audiometers and transducers capable of producing these high-frequency stimuli at the necessary amplitude and fidelity but still maintaining a reasonably flat response curve. Then there are also a vast number of smaller aspects which still need clarification, e.g., high-frequency interaural attenuation, inter subject variability in responding to highfrequency sounds, etc. Quite a number of large-scale studies of high-frequency hearing can be found in the literature (Rosen, Plester, El-Mofty, and Rosen, 1964; Zislis and Fletcher, 1966; Harris and Myers, 1971; Northern, Downs, Rudmose, Glorig and Fletcher, 1971). It is, however, practically impossible to compare results due to differences in audiometer, transducer, ear coupling, calibration methods and equipment, testing method and environment, population characteristics, selection criteria and very high inter- and intra-individual variability. As such, no normative audiometric threshold values exist for high-frequency audiometry (Fausti, Frey, Erickson and Rappaport, 1979; Fletcher, 1965; De Seta, Bertoli and Filipo, 1985; Gauz and Smith, 1985; Henry, East, Nguyen, Paolinelli and Ayors, 1985).

Furthermore it has been found that certain drugs like the polycyclic amines, especially the aminoglycocide antibiotic tobramycin, has a very high melanin affinity (Potts, 1962a; 1962b; 1964a; 1964b; Potts and Au, 1971; 1976; Lindquist, 1973). Add to this the fact that melanin is present in quite large quantities in the cochlea, as first reported by the Italian anatomist Alfonso Corti as far back as 1851. This may be an important factor in the etiology of drug induced ototoxicity (Dencker and Lindquist, 1975; Dencker, Lindquist and Ullberg, 1975; Wästerström, 1984; Wästerström, Brendberg, Lindquist, Lyttkens and Rask-Anderson, 1986).

Due to the earlier-mentioned problems encountered when trying to measure high-frequency thresholds, a new type of 
high-frequency audiometer, the Tonndorf Audimax Model 500, has recently been developed which could possibly bypass most of these problems (Tonndorf and Kurman, 1984). This audiometer works on the principle of electrostimulation. The test signal is superimposed on a modulated carrier frequency and is delivered via mylar-coated electrodes into the skin over each mastoid (fig. 1.). As the subject is then capacitatively coupled to the electrodes, no real current flows between the electrodes and the subject. Numerous studies have identified electrostimulation as a order to guard against possible renal failure. Any renal failure during this period would have resulted in very high serum levels due to the accumulation of tobramycin in the bloodstream.

The hearing test battery as mentioned above was repeated post-operatively on day 3 , day 6 , day 13 and day 20 . On postoperation (PO) day 21 she was discharged from hospital. Three months later when she came to hospital for a followup examination her hearing was tested again according to

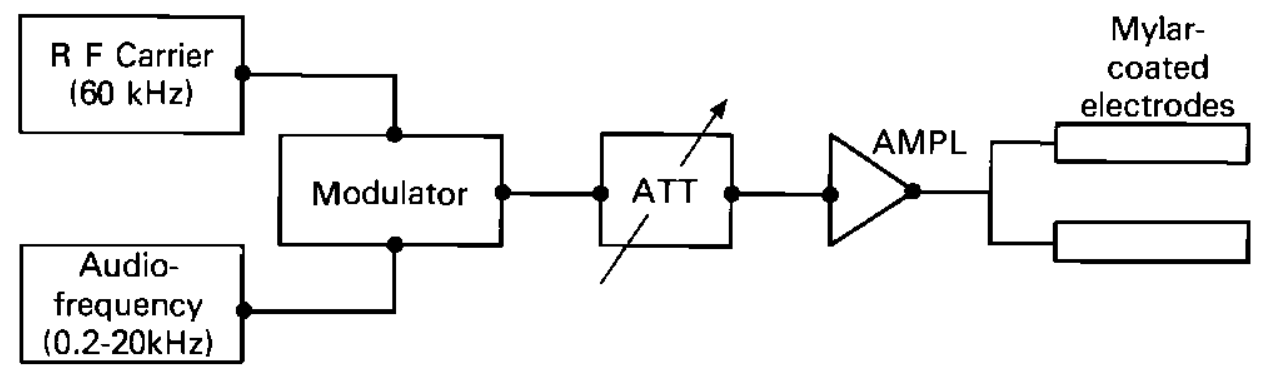

Fig 1: Schematic of high-frequency audiometer (From: Tonndorf and Kurman, 1984)

means of audio-transmission of electromechanical vibration in the bone and tissue structures surrounding the inner ear and the cochlea. Thus it would appear that the subject's bone-conduction hearing is being tested (Sommers and Von Gierke, 1964). This audiometer tests frequencies from 200 $\mathrm{Hz}$ right up to $20 \mathrm{kHz}$ in $200 \mathrm{~Hz}$ steps. The stimulus intensities can be adjusted from 0 to 120 electrostimulation hearing threshold levels (ESHTL) in 1 ESHTL step sizes. Zero to 120 ESHTL corresponds with zero to $60 \mathrm{~dB}$ SPL.

It was therefore decided to use this new audiometer to monitor the very early ototoxic effect of tobramycin on the high-frequency hearing of a Black çardiac surgery patient in Ga-Rankuwa Hospital, near Pretoria.

\section{METHODOLOGY}

The subject for this case report is a 25 year old Black woman who required open-heart surgery. She had to use tobramycin prophylactically for a period starting immediately after the operation. Before the operation her hearing was tested on two consecutive days by impedance audiometry, conventional pure tone audiometry and high-frequency audiometry. Seeing that both ears tested almost identically the test results for left and right ears were combined. As no standardized norms for high-frequency thresholds exist, it was decided to use the first two high-frequency test results as the biological baseline.

On the day of the operation she received $40 \mathrm{mg}$ tobramycin and thereafter the consecutive doses were altered so that the tobramycin serum levels were maintained between a trough of not less than $2 \mu \mathrm{g} / \mathrm{ml}$ and a peak not exceeding $10 \mu \mathrm{g} / \mathrm{ml}$. This range is considered ototoxically safe (Matz, 1986). The tobramycin regimen was continued for 72 hours. Throughout this period, the tobramycin blood serum levels were carefully monitored, as well as the renal functioning, in the above test battery. The initial two tests before the operation served to check on test-retest reliability and also served as the control test against which all further test results were to be compared.

\section{RESULTS}

On impedance audiometry no differences could be detected for consecutive tests except for very small variations in middle-ear pressure. All the other impedance test results (maximum compliance, acoustic reflex thresholds) remained essentially the same throughout the test period.

Conventional pure tone audiometry test results also remained essentially unchanged, with only about $5 \mathrm{~dB}$ total differences in thresholds between tests.

High-frequency audiometry, on the other hand, showed marked changes (fig. 2). The first two pre-operation test results were decidedly identical, indicating very good testretest reliability. On PO day 3 there was a very clear decrease in high-frequency sensitivity, especially at the high end of the hearing range. This decrease continued as is shown on the PO day 6 test. On PO day 13 there was a marked recovery, but not back to the original pre-operation hearing levels. The last test before the patient was discharged on PO day 20 indicated that the recovery process had ceased and the test results were similar to those of PO day 13. The follow-up test done 3 months after discharge from hospital matched that of PO days 13 and 20, thus indicating that there was no further recovery whatsoever. It is to be noted that this patient did not suffer from any'renal dysfunction during the entire period. Thus there was no possibility of tobramycin accumulation due to renal failure which could have led to the tobramycin exceeding the ototoxically safe upper serum level of $10 \mu \mathrm{g} / \mathrm{ml}$. 


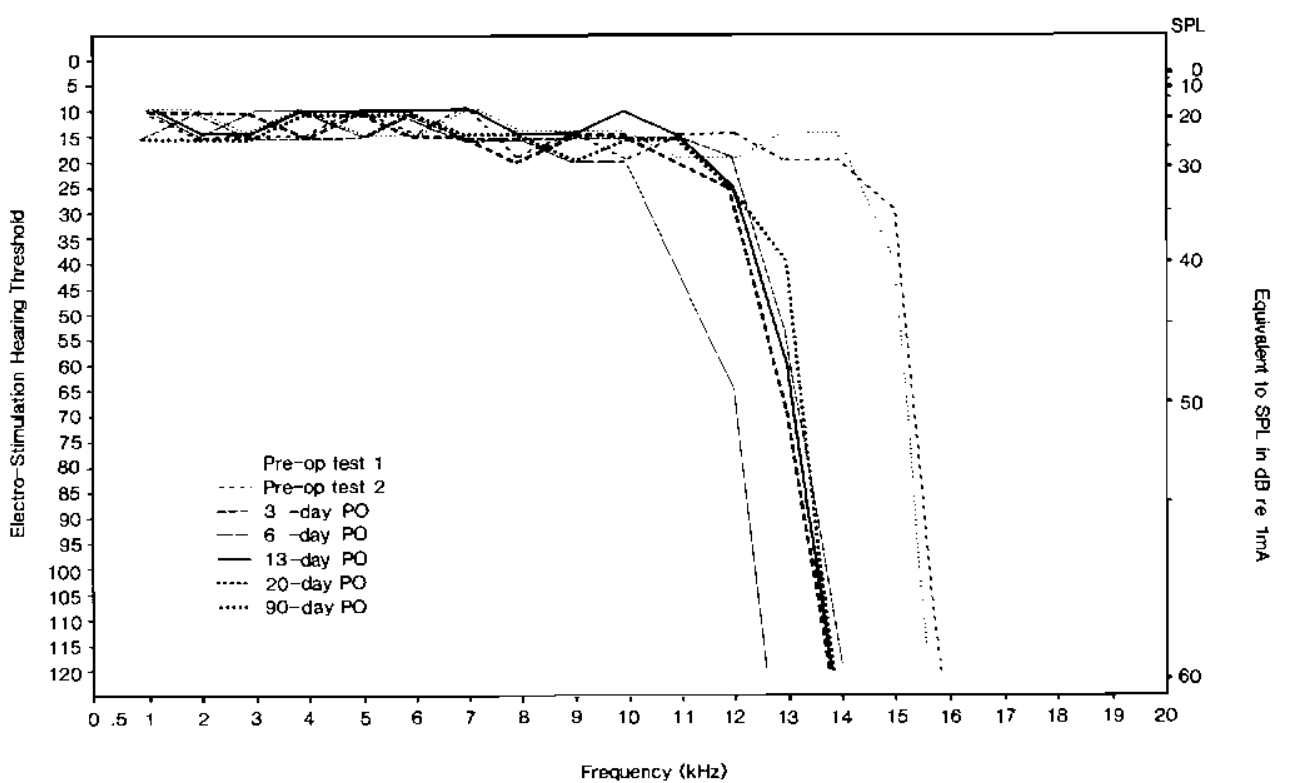

Fig 2: High-frequency threshold changes over time

\section{DISCUSSION}

It would appear that high-frequency audiometry by electrostimulation shows very good test-retest reliability, seeing that the average difference in thresholds between the first two tests was no larger than 5 ESHTL units, corresponding to about 2,0 to $2,5 \mathrm{~dB}$ SPL.

High-frequency audiometry could detect ototoxicity at a very early stage, as well as the severity of damage and recovery from damage, whilst standard audiometry and im. pedance tests were still showing no effects whatsoever of ototoxicity on hearing sensitivity.

It is clear from fig. 2 that the otoxic effect continued long after cessation of drug administration and long after the sérum levels indicated no drug residue in the bloodstream. This might be further proof of the possible accumulation of this drug on the melanin of the inner ear. This accumula. tion could, however, not be proved in this case study as no biopsies could be taken from or histological examinations done on the patient's inner lear. On the other hand, if the drug really accumulates in the inner ear, the monitoring of drug/serum levels would be of no use, since it would not represent the actual level of tobramycin in the inner ears. It may also be possible that Blacks have more melanin in the inner ear than Whites (Dencker and Lindquist, 1975; Dencker et al. 1975) and are thus more susceptible to ototoxic damage, but this is only speculative as no human experimental data on this aspect could be found in the literature. This possibility has, however, been proven in a study done on albino and pigmented guinea pigs (Wästerström, 1984; Wästerström et al. 1986).

Thus it would appear that the "safe" serum levels for ototoxic drugs were based on hearing tests for frequencies up to $8 \mathrm{kHz}$ only and may really not be safe at all. It would appear that the monitoring of patients for drug-induced ototoxicity should rather be done by high-frequency audiometry or a combination of measuring blood/serum levels and high-frequency audiometry.

\section{CONCLUSION}

High-frequency electrostimulation audiometry seems to show good test-retest reliability. It is also very effective in the early detection of ototoxicity, compared to standard audiometry. Ototoxic drug accumulation, possibly on the melanin in the inner ear will have to be investigated further. Also the possibility of Blacks having more melanin in the inner ear and thus a higher susceptibility to drug-induced ototoxicity needs further research. Lastly, a thorough investigation of present ototoxically "safe" serum levels is required.

\section{ACKNOWLEDGEMENTS}

The loan of the Tonndorf Audimax 500 High-Frequency Audiometer by the Needler Westdene Organization Pty Ltd, Johannesburg is acknowledged with thanks.

\section{REFERENCES}

Dencker, L. and Lindquist, N.G. Distribution of Labelled Chloroquinine in the Inner Ear. Arch. Otolaryngol., 101, 185-188, 1975.

Dencker, L., Lindquist, G.G. and Ullberg, S. Distribution of ${ }^{125}$ I-labelled Chloroquinine Analogue in a Pregnant Macaca Monkey. Toxicology, 5, 255-265, 1975.

De Seta, E., Bertoli, G.A. and Filipo, R. High Frequency Audiometry above $8 \mathrm{kHz}$. Audiology, 24, 254-259, 1985.

Fausti, S.A., Frey, R.H., Erickson, D.A. and Rappaport, B.Z. 2AFC Versus Standard Clinical Measurement of High Frequency Auditory Sensitivity $(8-20 \mathrm{Kc} / \mathrm{s}) . J$. Aud. Res., 19, 151-157, 1979.

Fee $_{i}$ W.E. Aminoglycoside Ototixicity in the Human. Laryngoscope, 90, (suppl 24), 1-18, 1980.

Fletcher, J.L. Reliability of High Frequency Thresholds. J. Aud. Res., 5, 133-137, 1965.

Gauz, M.T. and Smith, M.M. The Simplified HF E-800 Audiometer : Calibration and Normative Aspects. J. Aud. Res., 25, 101-122, 1985.

Harris, J.D. and Myers, C.K. Tentative Audiometric Hearing Threshold Level Standards From 8 Through 18 Kilohertz. J. Acoust. Soc. Am., 49, 600-601, 1971. 
Henry, K.R., East, G.A., Nguyen, H.H., Paolinelli, M.C. and Ayors, N.M. Extra-High-Frcquency Auditory Thresholds: Fine Structure, Reliability, Temporal Integration and Relation to Ear Canal Resonance. Audiol., 24, 92-103, 1985

Lane, R.J.M. and Routledge, P.A. Drug-Induced Ototoxicity. Drugs, $26,124-147,1983$

Lindquist, N.G. Accumulation of Drugs on Melanin. Acta Radiol. (Stockh) Suppl. 325, 1-92, 1973.

Matz, G.J. Aminoglycoside Ototoxicity, Am. J. Otolaryngol., 7 , $117-119,1986$.

Northern, J.L., Downs, M.P. Rudmose, W., Glorig, A. and Fletcher, J.L. Recommended High-Frequency Audiometric Threshold Levels (8000-18000 Hz). J. Acoust. Soc. Am., 52, 585-597. 1971.

Potts, A.M. The Concentration of Phenothiazines in the Eye of Experimental Animals. Invest. Opthalmol., 1, 522-530, 1962a.

Potts, A.M. Uveal Pigments and Phenothiazine Compounds, Tr. Am. Opthalmol. Soc., 60, 517-552, 1962 b.

Potts, A.M. Further Studies Concerning the Accumulation of Polycyclic Compounds on Uveal Melanin. Invest. Opthalmol 3, 399-404, 1964a.

Potts, A.M. The Reaction of Uveal Pigment in Vitro with Polycyclic Compounds. Invest. Opthalmol., 3, 405-416, 1964b.

Potts, A.M. and Au, P.C. Thallous Ion and the Eye. Invest. Op thalmol, 10, 925-931, 1971 .

Potts, A.M. and Au, P.C. The Affinity of Melanin for Inorganic
Ions. Exp. Eye Res., 22, 487-491, 1976.

Rosen, S., Plester, D., El-Mofty, A. and Rosen, H. High Frequency Audiometry in Presbycusis. Arch. Otolaryngol, 79, 25-35, 1964.

Schuknecht, H.F. Pathology of the Ear. Cambridge, Massachusets: Harvard University Press, 1974.

Smith, C.R., Lipsky, J.J., Laskin, O.L., Hellman, D.B., Mellits, E.D., Longstreth, J. and Lietman, P.S. Double Blind Comparison of the Nephrotoxicity and Auditory Toxicity of Gentamycin and Tobramycin. N. Engl. J. Med, 302, 1106-1108, 1980

Sommers, H.C. and Von Gierke, H.E. Hearing Sensations in Electric Fields. Aerospace Med., 35, 834-839, 1964

Stinson, M.R. Audiometry and the Geometry of the Human Ear Canal. CAA Symposium, Quebec City, 1984.

Tonndorf, J. and Kurman, B. High Frequency Audiometry. Ann. Otol Rhinol. Laryngol., 93, 576-582, 1984

Wästerström, S. Accumulation of Drugs on Inner Ear Melanin: Therapeutic and Ototoxic Mechanisms. Scand. Audiol. Suppl. $23,1-40,1984$.

Wästerström, S., Bredberg, G., Lindquist, N.G., Lyttkens, L. and Rask-Andersen, H. Ototoxicity of Kanamycin in Albino and Pigmented Guinea Pigs I: A Morphologic and Electrophysiologic Study. Am. J. Otol., 7, 11-18, 1986.

Zislis, T. and Fletcher, J.L. Relation of High-Frequency Thresholds to Age and Sex. J. Aud. Res., 6, 189-198, 1966. 


\section{NEW AUTOMATIC HEARING AID}

\section{A truly advanced and innovative sound amplifier}

The AUTOMATIC SOUND PROCESSOR (ASP) was developed especially for those people who have difficulty in hearing speech in noisy environments. For years, hearing aid wearers have avoided restaurants, theatres, church and parties because of the inability of an ordinary hearing aid to control background noises.

The A.S.P. is simply and uniquely designed to normalize background noise so that speech is more easily understood.

To be able to restore sound to even one human being makes your life especially important.

\section{To restore hearing... what a blessed talent to have}

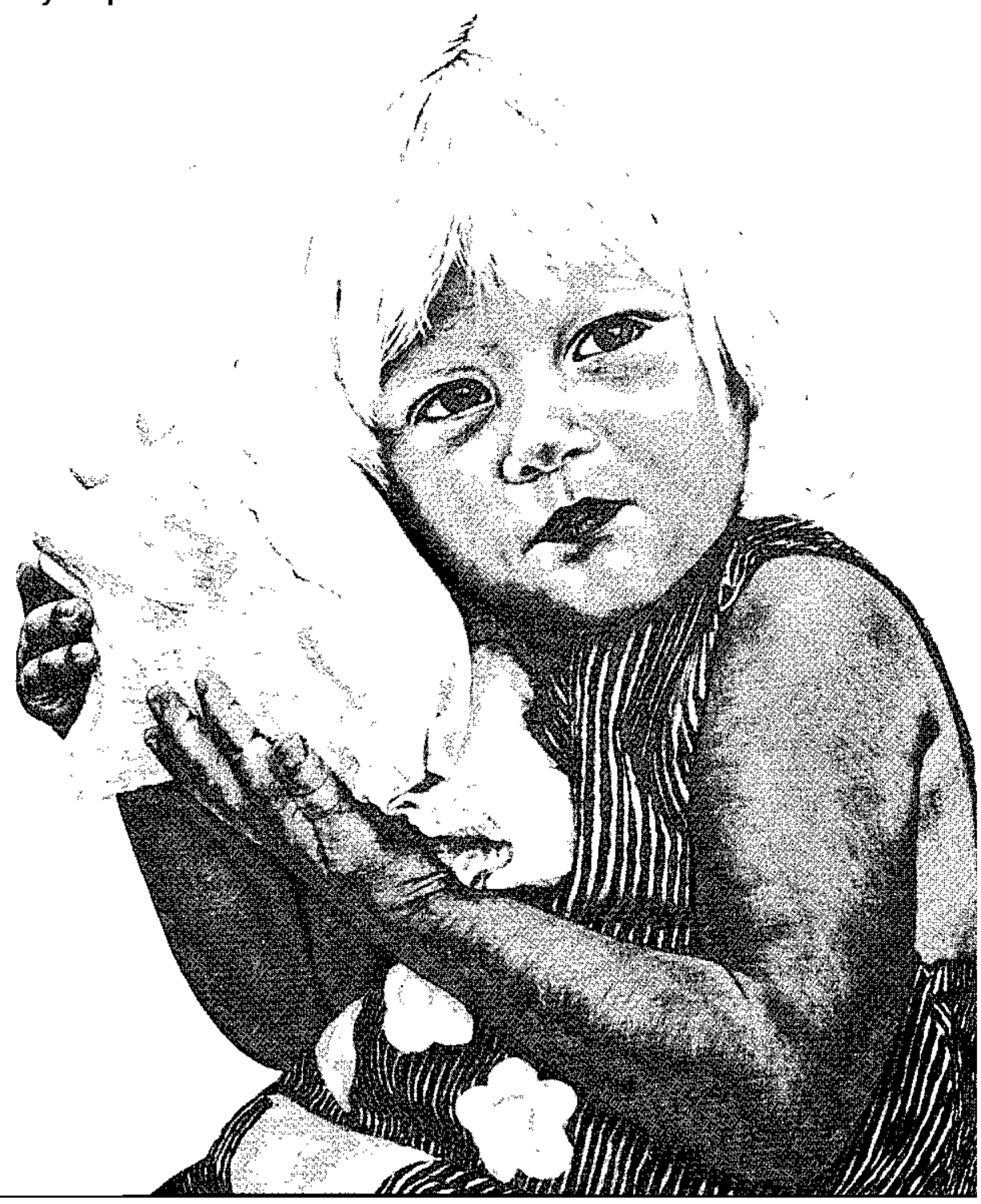

MEDIFIX Hearing System co.

SURGICAL \& MEDICAL

P.O. Box 19

Bedfordview

2008

South Africa

Phonc: (011) 53-4188/9

\begin{tabular}{|c|c|}
\hline CAPE & \\
\hline P.O. Box 52 & NATAL \\
\hline Lynedoch & P.O. Box 47443 \\
\hline $\begin{array}{l}7603 \\
\text { Phone: (02234) } 442\end{array}$ & $\begin{array}{l}\text { Greyville } \\
4023\end{array}$ \\
\hline or $\quad(02231) 93442$ & Phone: (031) 236164 \\
\hline
\end{tabular}

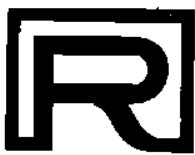

RICHARDS hearing systems

Tomorrow's Technology for Today's Hearing Problem 


\section{INFORMATION FOR CONTRIBUTORS}

The South African Journal of Communication Disorders publishes reports and papers concerned with research, or critically evaluative theoretical, or therapeutic issues dealing with disorders of speech, voice, hearing or language, or on aspects of the processes underlying these.

The South African Journal of Communication Disorders will not accept material which has been published elsewhere or that is currently under review by other publications.

All contributions are reviewed by at least two consultants who are not provided with author identification.

Form of Manuscript. Authors should submit four neatly typewritten manuscripts in triple spacing with wide margins which should not exceed much more than 25 pages. Each page should be numbered. The first page of two copies should contain the title of the article, name of author/s, highest degree and address or institutional affiliation. The first page of the remaining two copies should contain only the title of the article. The second page of all copies should contain only an abstract ( 100 words) which should be provided in both English and Afrikaans. Afrikaans abstracts will be provided for overseas contributors. All paragraphs should start at the left margin and not be indented.

Major headings, where applicable, should be in the order of METHOD, RESULTS, DISCUSSION, CONCLUSION, ACKNOWLEDGEMENTS and REFERENCES.

Tables and Figures should be prepared on separate sheets (one per table/figure). Figures, graphs and line drawings must be originals, in black ink on good quality white paper. Lettering appearing on these should be uniform and professionally done, bearing in mind that such lettering should be legible after a $50 \%$ reduction in printing. On no account should lettering be typewritten on the illustration. Any explanation or legend should not be included in the illustration but should appear below it. The titles of tables and figures should be concise but explanatory. The title of tables appears above, and of figures below. ,Tables and figures should be numbered in order of appearance (with Arabic numerals). The amount of tabular and illustrative material allowed will be at the discretion of the Editor (usually not more than 6).

References. References should be cited in the text by surname of the author and date, e.g. Van Riper (1971). Where there are more than two authors, et al. after the first author will suffice. The names of all authors should appear in the Reference List. References should be listed alphabetically in triple-spacing at the end of the article. For acceptable abbreviations of names of journals, consult the fourth issue (October) of DSH ABSTRACTS or The World List of Scientific Periodicals. The number of references used should not exceed much more than 20.

Note the following examples:

Locke, J.L. Clinical Psychology: The Explanation and Treatment of Speech Sound Disorders. J. Speech Hear. Disord., 48, 339-341, 1983.

Penrod, J.P. Speech Discrimination Testing. In J. Katz (Ed.) Handbook of Clinical Audiology, 3rd ed., Baltimore: Williams \& Wilkins, 1985.

Van Riper, C. The Nature of Stuttering. Englewood Cliffs, New Jersey: Prentice-Hall, 1971.

Proofs. Galley proofs will be sent to the author wherever possible. Corrections other than typographical errors will be charged to the author.

Reprints. 10 reprints without covers will be provided free of charge. All manuscripts and correspondence should be addressed to:

The Editor,

South African Journal of Communication Disorders,

South African Speech and Hearing Association,

P.O. Box 31782, Braamfontein 2017, South Africa.

\section{INLIGTING VIR BYDRAERS}

Die Suid-Afrikaanse Tydskrif vir Kommunikasieafwykings publiseer verslae en artikels oor navorsing, of krities evaluerende artikels oor die teoretiese of terapeutiese aspekte van spraak-, stem-, gehoor- of taalafwykings, of oor aspekte van die prosesse onderliggend aan hierdie afwykings.

Die Suid-Afrikaanse Tydskrif vir Kommunikasieafwykings sal nie materiaal aanvaar wat reeds elders gepubliseer is, of wat tans deur ander publikasies oorweeg word nie.

Alle bydraes word deur minstens twee konsultante nagegaan wat nie ingelig is oor die identiteit van die skrywer nie.

Formaat van die Manuskrip. Skrywers moet vier netjies getikte manuskripte in 3-spasiëring en met breë kantlyn indien, en dit moet nie veel langer as 25 bladsye wees nie. Elke bladsy moet genommer wees.

Op die eerste bladsy van 2 afskrifte moet die titel van die artikel, die naam van die skrywer/s, die hoogste graad behaal en die adres of naam van hulle betrokke instansie verskyn. Op die eerste bladsy van die oorblywende twee afskrifte moet slegs die titel van die artikel verskyn. Die tweede bladsy van alle afskrifte moet slegs 'n opsomming ( 100 woorde) in beide Engels en Afrikaans bevat. Afrikaanse opsommings sal vir buitelandse bydraers voorsien word. Alle paragrawe moet teenaan die linkerkantlyn begin word en moet rie ingekeep word nie.

Hoofopskrifte moet, waar dit van toepassing is, in die volgende volgorde wees: METODE, RESULTATE, BESPREKING, GEVOLGTREKKING, ERKENNINGS en VERWYSINGS.

Tabelle en Figure moet op afsonderlike bladsye verskyn (een bladsy per tabel/illustrasie). Figure, grafieke en lyntekeninge moet oorspronklike weergawes wees en moet in swart ink op wit papier van 'n hoë gehalte gedoen word.

Letterwerk wat hierop verskyn moet eenvormig wees, professioneel gedoen word en daar moet in gedagte gehou word dat dit leesbaar moet wees na 'n $50 \%$-verkleining in drukwerk. Letterwerk by die illustrasie moet onder geen omstandighede getik word nie. Verkla- rings of omskrywings moet nie in die illustrasie nie, maar daaronder verskyn. Die byskrifte van tabelle moet bo-aan verskyn en dié van figure onderaan. Tabelle en figure moet in die volgorde waarin hulle verskyn, genommer word (met Arabiese syfers). Die hoeveelheid materiaal in die vorm van tabelle en illustrasies wat toegelaat word, word deur die redakteur bepaal (gewoonlik nie meer as 6 nie), Venwysings. Verwysings in die teks moet voorsien word van die skrywer se van en die datum, bv. Van Riper (1971). Waar daar meér as twee skrywers is, sal et al, na die eerste skrywer voldoende wees. Die name van alle skrywers moet in die Verwysingslys verskyn. Verwysings moet alfabeties in 3-spasiëring aan die einde van die artikel gerangskik word. Vir die aanvaarde afkortings van tydskrifte se titels, raadpleeg die vierde uitgawe (Oktober) van DSH ABSTRACTS of The World List of Scientific Periodicals. Die getal verwysings wat gebruik is, moet nie veel meer as 20 wees nie. Let op die volgende voorbeelde:

Locke, J.L. Clinical Phonology: The Explanation and Treatment of Speech Sound Disorders. J. Speech Hear. Disord., 48, 339-341, 1983.

Penrod, J.P. Speech Discrimigation Testing. In J. Katz (Ed.) Handbook of Clinical Audiology, 3de ed., Baltimore: Williams \& Wilkins, 1985.

Van Riper, C. The Nature of Stuttering. Englewood Cliffs, New Jersey: Prentice Hall, 1971.

Proewe. Galeiproewe sal waar moontlik aan die skrywer gestuur word. Die onkoste van veranderings, behalwe tipografiesé foute, sal deur die skrywer self gedra moet word.

Herdrukke. 10 herdrukke sonder omslae sal gratis verskaf word. Alle manuskripte en korrespondensie moet gerig word aan: Die Redakteur,

Die Suid-Afrikaanse Tydskrif vir Kommunikasieafwykings.

Die Suid-Afrikaanse Vereniging vir Spraak- en Gehoorheelkunde, Posbus 31782,

Braamfontein 2017, Suid-Afrika. 